\title{
ANALISIS TANGgUNG JAWAB PELAKU USAHA PT. JASA MARGa TERHADAP PELANGGARAN HAK KESELAMATAN KONSUMEN PENGGUNA JALAN TOL DITINJAU DARI PERATURAN PEMERINTAH NOMOR 15 TAHUN 2005 TENTANG JALAN TOL.
}

\author{
Mayskhye Techtonia \\ (Mahasiswa Program S1 Fakultas Hukum Universitas Tarumanagara) \\ (E-mail: Mayskhye.t@gmail.com)
}

\begin{abstract}
A.M Tri Anggraini
(Corresponding Author)

Dosen Fakultas Hukum Universitas Trisakti, Meraih Sarjana Hukum (S.H) dari Fakultas

Hukum Universitas Gajahmada (1988), Magister Hukum (M.H) dari Fakultas Hukum

Universitas Tarumanagara (1995), Doktor Ilmu Hukum (Dr) dari Fakultas Hukum
\end{abstract}

Universitas Indonesia (2003).

(E-mail : anggraini1601@gmail.com)

\begin{abstract}
Roads are one of the most important transportation infrastructures in people's lives and have an important role in the efforts to develop the life of the nation and state, especially the construction of toll roads that are safe and comfortable for journeys. But along with the development of the era, resulting in many problems that occur related to toll road safety, so the question arises: How is legal protection for consumers of toll road users in the right to safety on the highway? And How the Responsibilities of Business Actors PT. Jasa Marga regarding violations of consumer safety of toll road users in terms of Government Regulation Number 15 of 2005 concerning toll roads? As normative legal protection road users a toll had been arranged in several regulations which includes government regulation number 15 of 2005 and completed explicitly by law number 8 of 1999 on consumer protection. But what envisaged in the regulation in protecting and responsibility of have been given by PT. Jasa Marga not fully been implemented especially consumers road users toll in the soles safety on the highway.
\end{abstract}

Keywords: Toll Roads, Law Protection, Responsibilities of Business Actors, Rights Of Consumer Safety 


\section{PENDAHULUAN}

\section{A. Latar Belakang}

Seperti yang kita ketahui bahwa jalan merupakan sebuah penunjang utama untuk memudahkan segala sesuatu kegiatan maupun aktivitas yang dilakukan oleh masyarakat sehari-hari dengan menghubungkan suatu jalan raya atau lalu lintas dari satu tempat ke tempat lain yang memiliki peranan sangat bermanfaat perihal dalam berkembangnya suatu negara maupun bangsa. Lalu kemudian, juga memiliki bagian yang melaksanakan suatu target-target membangun didunia antara lain proses memeratakan yang dimulai dari negara maju melalui pemerintah untuk mendukung, mendorong usaha masyarakat demi mencapai suatu kemudahan prasarana di negara. Oleh karena itu, mendirikan sebuah prasarana masyarakat memenuhi segala yang dibutuhkan oleh kepentingan di era lingkungan yang ada baik di dalam kegiatan atau memindahkan barang maupun orang dengan selamat, terlindung dari segala hambatan yang berbahaya serta tentram agar memperoleh manfaat yang dinikmati oleh setiap lingkungan masyarakat. ${ }^{1)}$ Jalan pun juga merupakan bagian dari adanya perangkat unsur-unsur yang saling berkaitan dengan pengangkutan oleh berbagai jenis kendaraan yang meliputi dari suatu bangsa untuk memiliki tindakan dalam suatu peristiwa utama dimulainya mengenai pertimbangan dari sudut pandang atas tindakan perekonomian seperti jalan, semacam bagian yang berupa persediaan utama dan berkenaan kepada masyarakat agar terjadinya suatu perubahan dan menimbulkan suatu peristiwa diantara penghasilan pasar dan para pemakai jasa akhir. Dilihat dari kategori kepentingan umum dan kebudayaan yang sudah berkembang, dimana telah tersedia bagi perkembangan dilingkungan sejumlah manusia yang mampu menjadi sarana perubahan kepentingan umum, berdiri atas sifat penyimpangan yang masih dapat diterima, serta pulih atas hubungan budaya. Selanjutnya oleh kategori lingkungan dilihat dari adanya perlintasan yang disediakan untuk menunjang suatu proses membangun yang masih dalam tahap perkembangannya. Kemudian dari kategori politik, bisa dilihat dari adanya perlintasan yang menggabungkan suatu wilayah manapun, sedangkan dari kategori keamanan dan pertahanan, kehadiran perlintasan ini menyediakan jalan masuk dan kesiapsiagaan

${ }^{1)}$ C.S.T Kansil, Engelien Palandeng dan Altje Agustin Musa. Tindak Pidana Dalam UndangUndang Nasional, (Jakarta: Jala Permata Aksara, 2009), hal. 180. 
untuk bergerak dalam perbuatan menyelenggarakan sistem dari keamanan dan pertahanan. Dengan bertebarnya tempat baik sumber alam, tempat penghasilan pasar maupun pengguna jasa akhir, tentunya dituntut untuk mengikuti sistem menjalankan tugas dengan baik dalam menggabungkan tempat-tempat tersebut atas gambaran dalam bentuk ikatan perihal pembagian suatu wilayah tertentu. ${ }^{2}$

Perlunya diketahui definisi dari adanya suatu jalanan bebas hambatan yang dikenal sebagai Jalan Tol merupakan jalanan untuk orang banyak yang adalah bagian dari susunan yang teratur atas bagian yang menggambarkan lintasan yang berfungsi sebagai perlintasan suatu bangsa yang pengguna siapa pun yang mempunyai tanggung jawab untuk jalanan yang mengenakan biaya. Sebagai pengguna dari jalanan bebas hambatan adanya kewenangan-kewenangan menurut hukum jalanan Tol sebagai pengguna jasa yang perlu diketahui, dimana ketentuan ini diatur di dalam aturan yang telah dibuat oleh pemerintah antara lain UUPK Nomor 08 Tahun 1999 tentang pengguna jasa (Perlindungan Konsumen) dalam artikel 4 Huruf (A) menyebutkan bahwa kewenangan pengguna jasa meliputi kewenangan atas keadaan nyaman, bebas dari gangguan, dan terhindar fari bahaya dalam menggunakan muatan dan/ atau manfaat yang diperlukan bagi orang lain. Di dalam Artikel 7 huruf (D) aturan yang dibuat oleh pemerintah antara lain UUPK Nomor 08 Tahun 1999 tentang pengguna

jasa (Perlindungan Konsumen) memberikan suatu jaminan selama bisa memenuhi suatu hak tersebut dengan menetapkan kewajiban kepada pelaku usaha untuk menjaminkan suatu kualitas dari barang/jasa yang diperjual/ beliakan harus sesuai dengan ketetapan standar kualitas suatu muatan dan/ atau manfaat yang diperlukan bagi orang lain. Namun nyatanya, beberapa pengguna konsumen jalan tol masih banyak yang tidak mendapatkan standar pelayanan minimal yang telah ditetapkan dalam ketentuan yang berlaku tersebut sehingga sampai saat ini sebagai konsumen keadaan ini jarang terdapat selama memperoleh kewenangan menurut hukum sebagai konsumen pengguna jasa layanan di jalanan bebas hambatan.

Mengenai hal-hal seputar konsumen pengguna di jalan tol. Sekitar belakangan ini banyaknya peristiwa-peristiwa yang sering merugikan antara pihak-pihak yang terjadi di kawasan jalan tol yaitu misal, salah satunya Insiden orang yang melemparkan batu di KM 6,300 Jalan bebas hambatan Jakarta Cikampek, Pondok Gede Bekasi. Kejadian ini terjadi

\footnotetext{
2) Ibid.
} 
pada Selasa, 5 Juni tahun 2018. Sebuah mobil yang melintas di jalan Tol tersebut dilempari bongkahan batu sebesar bola sepak dari atas jembatan penyeberangan orang (JPO), Pada dasarnya Jalan penghubung atau biasa yang disebut dengan jembatan yaitu jalanan dari beton yang direntangkan diatas sungai atau jalanan pelengkap lalu lintas atas terputusanya di ke 2 ujung atas adanya hambatan yang ada di wilayah tersebut misalnya saluran serta jalanan raya atau jalanan seperti rel kereta api yang menyilang. Sedangkan Jembatan Penyeberangan Orang (JPO) merupakan sarana jalanan yang menghubungkan orang yang biasanya berjalan kaki selama menyebrang perlintasan yang ramai dan luas seperti jalanan Tol, sehingga aktivitas perlintasan kendaraan atau orang dapat dipisah. Kriteria Jembatan Penyeberangan Orang alias JPO agar mengarah ke tangga dan tidak menyebrang dibawah jalan tol ini meliputi pagar pengaman untuk mengarahkan pejalan kaki yang aman, nyaman, dan selamat. Struktur dari Jembatan Penyeberangan Orang ini harus diperhatikan dan harusnya rutin dilakukan pemeliharaan berkala, namun nyatanya kondisi kawat yang berada di jembatan penyeberangan orang itu sudah tidak layak yang mana kondisi tersebut sudah berbolong, Tujuan dari dari kawat pembatas yang ada di jembatan penyeberangan ialah untuk mengantisipasi atas terhindarnya dari hal-hal berbahaya seperti perihal adanya celaka lalu lintas dari atas JPO ke jalan tol atau orang yang melompat bunuh diri dan lain sebagainya, dalam kasus ini ada dua mobil yang menjadi korban pelemparan batu.

Awal mula terjadinya kasus ini pada pukul 04.00 WIB dimana peristiwa itu berawal ketika Saeful Mazazi Korban pertama yang berumur 43 tahun warga dari Danawari, Kecamatan Balapulang, Kabupaten Tegal, Tengah mengendarai mobil Toyota Cayla dengan Nomor Polisi G-8696-ZP yang hendak mudik ke Tegal, Jawa Tengah, bersama keluarganya. Namun secara tidak diduga, mobil yang sedang dikendarainya dilempari bongkahan batu koral penutup decker dan hebel yang besarnya seukuran bola sepak dari atas JPO Jatibening oleh seseorang yang tidak dikenal, hingga kaca mobil tersebut pecah. Seketika mobil yang dikemudikan korban hilang kendali. Namun istri dari korban yang duduk di sebelahnya dengan sigap mengambil alih stir untuk mengendalikan laju mobil dan membelokan mobil ke arah kiri, untuk menepikan mobil ke bahu jalan. Selang beberapa menit kemudian, satu pengendara lainnya yang mengendarai mobil Toyota Avanza dengan Nomor Polisi B-1056-ERF juga mengalami hal yang sama. Kedua korban kemudian menepi ke bahu jalan tol. Pada pukul 05.00 WIB Tim Patroli Jalan Raya (PJR) Tol Jakarta-Cikampek mendatangi lokasi kejadian, petugas menemukan para 
korbandi lokasi kejadian. Akan tetapi, korban yang bernama Saeful Mazazi tewas dilokasi kejadian akibat terkena pecahan batu yang mengenai pelipis kiri dan leher serta luka pada bagian dada sebelah kanan. Sementara pengendara mobil dari Toyota Avanza dengan Nomor Polisi B-1056-ERF selamat. Tim PJR akhirnya menghubungi Polsek Sektor Pondok Gede agar kasus ini segera ditindak lebih lanjut. Pukul 05.30WIB aparat polisi membawa korban Saeful Mazazi ke RSUD Bekasi untuk segera diautopsi. Pihak yang berwenang mengamankan kedua kendaraan milik korban. Sementara pengendara korban yang selamat dibawa ke kantor polisi untuk diperiksa. Usai peristiwa tersebut, mereka melakukan upaya penyiagaan 24 Jam petugas berseragam dinas maupun preman untuk pengamanan kepada masyarakat di JPO. Sementara itu polisi juga mengamankan beberapa alat bukti yaitu mobil Toyota Avanza dengan Nomor Polisi B-1056-ERF, mobil Toyota Cayla dengan Nomor Polisi G-8696-ZP, dan 3 buah batu. ${ }^{3)}$

Dari contoh kasus di atas maka perlu sekali diperlukan adanya memperlindungi kepastian hukum bagi pengguna jasa, oleh sebab itu diharapkan untuk semua suatu bangsa didunia ini yang lebih dikhususkan lagi kepada NKRI untuk bangkit atas melindungi jaminan dan kepastian hukum atas pengguna jasa yang nyatanya dirugikan tersebut agar dapat terpenuhinya hak-hak konsumen. ${ }^{4}$ Itulah mengapa hal ini menjadikan sebagai alasan para pengguna jasa yang dirugikan menuntut hak nya kepada pelaku usaha, akan tetapi pengguna jasa tersebut belum dilindungi akan kepastian hukum yang tepat, diakibatkan kurangnya perlindungan kepastian hukum untuk para pengguna jasa yang telah diberikan oleh pelaku usaha atas kerugian tersebut. ${ }^{5)}$

\section{B. Perumusan Masalah}

Atas hal nya latarbelakang seperti yang telah dikemukakan diatas, Hingga penulis dapat mengambil adanya suatu rumusan masalah yaitu:

1. Bagaimana Perlindungan Hukum terhadap konsumen pengguna jalan tol dalam hak keselamatan di jalan tol?

\footnotetext{
${ }^{3)}$ https://m.detik.com/news/berita/4060679/pelemparan-batu-ke-mobil-di-tol-dari-jpopondok-gede-terjadi-2-kali diakes pada tanggal 10/08/2018.

${ }^{4)}$ Eli Wuria Dewi, Hukum Perlindungan Konsumen, (Yogyakarta: Graha Ilmu, 2015), hal. 5.

5) Ibid, hal. 3.
} 
2. Bagaimana Tanggung Jawab Pelaku Usaha PT. Jasa Marga terhadap pelanggaran keselamatan konsumen pengguna jalan tol ditinjau dari Peraturan Pemerintah No. 15 tahun 2005 tentang jalan tol?

\section{Metode Penelitian}

\section{Jenis Penelitian}

Dalam penulisan penelitian skripsi ini Penulis menggunakan jenis penelitian Hukum Normatif yang menurut Peter M. Marzuki yaitu: ${ }^{6)}$ penelitian ini memberikan sebuah perbuatan yang menjelaskan secara teratur menurut sistem yang baik suatu aspek hukum tertentu untuk mengetahui keadaan hubungan antara aturan wilayah sulit yang sebenarnya sehingga dapat memprediksi masa yang akan datang.

\section{Sifat Penelitian}

Penulis menggunakan spesifikasi bersifat penelitian deskriptif. Yaitu mewujudkan suatu individual maupun kelompok orang yang secara tepat akan sifat.

\section{Jenis Pengumpulan Data}

Data penelitian yang digunakan penulis ada 3 (tiga) macam jenis yaitu:

a. Bahan Hukum Primer:

1) Undang-Undang Nomor 8 Tahun 1999 Tentang Perlindungan Konsumen;

2) Peraturan Pemerintah Nomor 15 Tahun 2005 Tentang Jalan Tol;

3) Undang-Undang Nomor 38 Tahun 2004 Tentang Jalan.

b. Bahan Hukum Sekunder, yang dipakai penulis yaitu buku-buku, artikel skripsi, tesis, journal hukum, dan kamus-kamus hukum.

\footnotetext{
${ }^{6)}$ Ibid., hal.32.
} 
c. Bahan Hukum Nonhukum : KBBI, ensiklopedia, hasil data wawancara selama menganalisis peulisan yang dikaji dalam penelitian ini.

\section{Teknik Pengumpulan data}

Dalam penelitian ini penulis menggunakan metode pengumpulan data dokumen, studi pustaka serta hasil wawancara yang berupa pengumpulan data terkait dengan hal penelitian yang akan dikaji. selain itu berbagai rujukan buku dan beberapa bahan hukum pendukung lainnya juga dikumpulkan kemudian diferifikasikan kesesuainnya dengan kebutuhan penulis serta melakukan wawancara kepada narasumber-narasumber yang akan dituju.

\section{Telaah Bahan Hukum}

Bahan Pendekatan yang dipakai oleh Penulis dalam penulisan akan skripsi ini yaitu pendekatan oleh undang-undang (statue approach) dan juga bahan pendekatan kasus (case approach).

\section{PEMBAHASAN}

Demi menunjang suatu perkembangan atau kemajuan suatu ekonomi, Negara Indonesia kita ini membutuhkan suatu jaringan perlintasan yang dapat dipercaya dan memberikan hasil yang nyata. Dalam Peraturan Pemerintah No. 04 Tahun 1978, disaat tanggal 01 Maret 1978 badan tertinggi yang memerintah suatu Negara mengadakan berdirinya PT. Jasa Marga (Persero) Tbk. Yang mana sasaran utama dari perusahaan Jasa Marga ini yaitu mengupayakan, proses membangun, pelaksanaan rencana yang telah dikembangkan dan mengusahakan jalanan ditol serta fasilitas yang telah disediakan agar jalanan ditol ini mampu menjalankan setiap tugasnya sebagimana mestinya berguna sebagai jalanan yang bebas hambatan untuk memberikan kegunaan lebih tinggi dibandingkan terhadap jalanan bukan tol 
melainkan jalanan biasa atau umum. Di awal berdirinya dalam perusahaan ini, peran dalam perseroan bukan hanya operator saja akan tetapi memiliki tanggungjawab atas kekuasaan jalanan bebas hambatan di negara kita ibu Pertiwi ini. Sampai pada tahun 1987-an Perusahaan Jasa Marga ini merupakan perusahaan yang satu-satunya menyelenggarakan jalan bebas hambatan di negeri ini yang pembangunannya dibiayai badan negara dengan dana yang diperoleh dari peminjaman diluar negara bahkan proses dalam menerbitkan suatu surat pinjaman dengan bunga tertentu yang telah dikeluarkan oleh perusahaan Jasa Marga dan merupakan yang sepatutnya Jalan bebas hamabatan pertama di negera Indonesia yang pelaksanaan kerjanya telah dikembangkan oleh Perseroan, Jalanan tol Jakarta Bogor dan Ciawi atau yang disebut dengan jagorawi adalah peristiwa yang sangat penting dalam suatu sejarah dalam perihal berkembang industri jalanan bebas hambatan ditanah air kita, proses pengoperasian pertama kalinya dimulai pada tahun 1987. Dan diakhir dasarwasa tahun 80-an badan negara Indonesia mulai turut berbuat sesuatu secara bersama kepada bagian swasta agar ikut serta atas proses membangun jalan layang dalam cara kerja suatu Built/pendirian, Operate/pengoperasian dan Transfer/pemindahan yang biasa dsingkat dengan BOT. Dalam dasarwasa tahun 1990-an Perseroan condong bertindak sebagai hak yang mempunyai suatu kewenangan atas tindakan yang memberikan fasilitas kepada pengusaha-pengusaha swasta yang sebagian dari mereka gagal dalam tanggung jawabnya atas proyek. Sebagian jalanan tol yang memegang pengalihan yaitu Cipularang dan JORR. Dengan adanya aturan yang dibuat oleh badan negara Undang-Undang No. 38 tahun 2004 tentang Jalan juncto. Undang-Undang No. 13 tahun 1980 lalu terbitnya Peraturan Pemerintah No. 15 telah menyusun yang bersifat 
lebih khusus tentang jalan bebas hambatan ini dimana sudah berlaku peralihan atas cara kerja suatu bidang usaha jalanan bebas hambatan yang meliputi yaitu membentuk Badan Pengatur Jalan Tol (BPJT) semacam alat pengatur kecepatan di perusahaan jalan layang di negara Indonesia, dan juga menetapkan harga pungutan jasa ditol oleh kepala suatu departemen negara pekerjaan umum yang menyesuaikan tiap 2 tahun. Dengan begitu, tindakan yang dilakukan oleh seseorang yang memiliki adanya kewenangan tersebut mengembalikan dari perseroan kepada badan usaha negara. Sebagiamana akibatnya, Perseroan yang melakukan tugas agar berjalan semestinya sebuah perusahaan yang melakukan kegiataan pengadaan dan yang bertugas menjalankan kewajiban jalanan ditol yang memperoleh ijin pemeliharaan jalan bebas hambatan oleh badan usaha negara. ${ }^{7)}$

Pada tanggal 09 Desember 2018, Penulis bertemu dengan Bapak Dr. Refly Harun, S.H., M.H., LLM, selaku Komisaris PT. Jasa Marga (Persero) periode 2015-2018, Ahli Hukum Tata Negara yang juga selaku dosen Fakultas Hukum di Universitas Tarumanagara. Berdasarkan pertanyaan yang penulis berikan, beliau memberikan tanggapan bahwa kasus tersebut terjadi pada saat liburan lebaran dimana yang bertanggung jawab pada saat itu tidak hanya urusan pengelola jalan tol saja, perlu diketahui pengelola jalan tol ini terbagi atas dua yaitu : yang pertama adalah Badan Usaha Jalan Tol (BUJT) yang di dalamnya termasuk seperti Perusahaan PT.Jasa Marga Tbk, dan yang kedua yaitu Badan Pengelola Jalan Tol (BPJT). BPJT ini adalah Lembaga yang dibawah Kementerian PUPR sebagai regulatornya jalan tol, dulunya PT. Jasa Marga Tbk ini menjadi regulatornya akan tetapi, regulator jalan tol yang 
sekarang yaitu pemerintah, sementara perusahaan PT. Jasa Marga ini menjadi salah satu pengelola Badan Usaha Jalan Tol (BUJT). Sebagai pengelola jalan tol, perusahaan ini bertanggung jawab atas ruas jalan tol yang dikelolanya termasuk dari aspek keamanan. Kembali lagi mengenai kasus pelemparan batu yang terjadi pada saat mudik libur lebaran tahun ini, yang terlibat bukan hanya Jasa Marga saja tetapi yang menangani atau yang mengambil alih langsung adalah pemerintah mengenai aspekaspek yang salah satunya aspek keamanan. Kita kaitkan dengan agenda politik kemarin dimana itu adalah mudik libur lebaran terakhir sebelum pilpres yang betulbetul dikelola secara sungguh-sungguh serta berhati-hati, dan in general mudik lebaran kemarin sangat sukses salah satunya tidak ada keluhan mengenai kemacetan yang signifikan walaupun sebenarnya tetap ada kemacetan pada saat H-2 mudik lebaran ini namun tidak seburuk dari tahun-tahun yang sebelumnya, bahkan tingkat kemacetan mudik lebaran yang sekarang jauh lebih baik. Ketika insiden tersebut ini terjadi di Jembatan Penyeberang Orang (JPO), perlu diiketahui sebelumnya bahwa JPO adalah jembatan yang berakses langsung ke masyarakat, yang fungsinya yaitu melewati dan menempuh perhubungan antara sebuah tempat dengan tempat lain yang berakhir pada ke 2 ujung jalan diakibatkan adanya halangan seperti jalan tol, JPO dibangunkan oleh BUJT. Banyaknya orang yang lewat di JPO ini dianggap kecolongan bagi pemerintah karena kasus tersebut, dan bisa saja adanya kemungkinan yang menjadi pelakunya yaitu orang jahil ataupun orang gila yang melempar batu tersebut, yang paling penting disini yaitu bagaimana penanganan pasca itu, beliau mengatakan bahwa Jasa Marga selalu bertanggung jawab terhadap kejadian di Jalan Tol bahkan diluar kontrol pengelola jalan tol misalnya, adanya seorang ibu hamil yang 
melahirkan di jalan tol dimana petugas sigap untuk menolong, mengamankan, serta menghubungi keluarga dari ibu tersebut. Menurut beliau, kejadian ini murni kecelakaan diluar kontrol dan menjadi evaluasi bagi seluruh pihak pengelola yang terlibat seperti pemerintah dan pihak kemananan untuk melihat setiap kondisi di jalan tol.

Kedua, didalam melaksanakan suatu tempat berlindung kepastian hukum tehadap kewenangan-kewenangan pengguna jasa layanan jalan bebas hambatan hingga beliau mengatakan bahwa Badan pengelola Jalan bebas hambatan merupakan alat pengatur kecepatan jalanan ditol telah menentukan sesuatu sebagai syarat agar setiap pihak pengelola pelaku usaha jalanan ditol menyediakan fasilitas yang sangat utama sebagai kontrasepsi proses membayar jalanan ditol kpada pengguna jasa layanan jalan bebas hambatan di jalan layang yang bersangkut pautkan atas pelaksanaan rencana yang telah dikembangkan terhadap jalanan bebas hambatan dalam segala putusan yang telah ditetapkan pengurus atau dewan pimpinan oleh perusahaan PT. Jasa Marga tercantum dalam No.181/tahun 2011 tentang Pedoman Petugas Pelayanan Lalulintas di jalanan bebas hambatan secara hal pokok-pokok masalah yang penting perihal penyelenggaraan usaha melayani kebutuhan pada wilayah jalan layang menjamin segala hal cara yang mengatur dan bebas dari gangguan yang ada di perlintasan jalan, tersedia adanya ketersediaan perbuatan mengatur dan dapat mengatasi sesuatu yang dikendarai tidak dapat berjalan atau bekerja sebagaimana mestinya, tersedia adanya ketersediaan hal yang mengatur kecelakaan dan adanya ketersediaan hal yang mengatur atas masalah dalam berjalan di waktu lainya. Lalu adanya ketersediaan hal yang mengatur atas masalah diwilayah yang berada jalanan ditol serta wilayah yang diawasi oleh jalanan bebas hambatan ini mempunyai potensi mendatangkan kekacauan yang ada seperti peristiwa terbakarnya sesuatu didaerah/bagian antara jalan milik jalanan ditol, masyarakat yang tidak mempunyai keperluan masyuk disekitar wilayah jalan tol, selain itu ada juga binatang ternak yang memasuki wilayah area jalan bebas hambatan, keadaan lalulintas yang tidak memenuhi 
prasayarat diakibatkan oleh sesuatu kerugian yang disebabkan oleh alam misalnya banjir, proses menderek paksa ( Penderekan yang tidak sah), dan juga hal-hal yang dapat menyebabkan ketidaklancaran akibat terjadinya kerugian yang disebabkan oleh alam lainnya. Adanya penggarapan dari lalulintas jalanan ditol yang terdiri atas penggarapan lalulintas yang memiliki kecpatan serta ukuran berat yang tidak memenuhi prasyarat prosedur yang telah termuat di dalam aturan yang dibuat oleh badan usaha negara dalam UU.No. 22 Tahun 2009"LaluLintas dan Angkutan Jalan" dan aturan untuk mengendarai suatu sasaran khusus yang berada diwilayah jalanan bebas hambatan, perusahaan PT. Jasa Marga tidak lupa atas hal-hal mengenai keluhan masyarakat yang segera ditindak lanjuti dan menyampaikan pemberitahuan atas kabar maupun berita tentang sesuatu lalulintas jalanan yang ada ditol lewat penyampaian pemberitahuan atas layanan jalan tol 14080 atau ditempatkeluar atau masuknya jalanan ditol, pusat layanan panggilan, layanan pesan variabel atau singkatan dari $V M S$, Pesan singkat, pemantauan dari kemera setiap sudut dan radio perusahaan yang telah bekerja sama dengan pelaku usaha PT. Jasa Marga. ${ }^{8)}$

\section{A. Perlindungan Hukum Terhadap Konsumen Pengguna Jalan Tol.}

Dalam pelaksanaan pekerjaannya yang secara nyata, sebagian dari pengguna jasa layanan jalan bebas hambatan ini ada saja yang tidak memperoleh prasarana jalanan ditol yang baik dimana ada terdapat kesulitan selama memperoleh kewenangan-kewenangan mereka sebagai pengguna jasa layanan perlintasan ditol.

\section{Menurut Undang-Undang Perlindungan Konsumen}

Adanya aturan yang dibuat oleh badan usaha negara UUPK Nomor.08 diTahun 1999 tentang Perlindungan Konsumen merupakan seluruh usaha

${ }^{8)}$ Wawancara langsung dengan Bapak Dr. Refly Harun, S.H., M.H., LLM, selaku Komisaris PT. Jasa Marga (Persero) periode 2015-2018, Ahli Hukum Tata Negara yang juga selaku dosen Fakultas Hukum di Universitas Tarumanagara pada hari Minggu tanggal 09 Desember 2018 Pukul 11.00 WIB bertempat di kediaman Rumah bapak Refly Harun daerah Kebon Jeruk, Jakarta Barat. 
yang menjadi keadaan perihal penerapan perangkat hukum yang mampu menjamin memberikan tempat berlindung hukum kepada pengguna jasa. ${ }^{9)}$ Tempat berlindungan para pengguna jasa didalam ketentuan aturan yang dibuat oleh badan negara yaitu UUPK No.08 diTahun 1999 yang adalah usaha-usaha dalam menanggung hadirnya perihal ketentuan aturan hukum bagi memberi tempat berlindungan hukum pada pengguna jasa. Usaha bagi menyerahkan sesuatu kepada tempat berlindungan aturan hukum pada konsumen sebagai cara menyerahkan kewajiban pertanggung jawabannya pada produsen amat diperlukan, melainkan bagi memberi keadaan yang sebanding antara wewenang dan sudah semestinya konsumen dan produsen, namun perlu menyerahkan sesuatu perihal ketetapan yang tentram, bebas dari gangguan dan terhindar dari bahaya pada konsumen yang menggunakan suatu produk muatan produsen yang menghasilkan muatan yang merugikan konsumen sudah selayaknya bertanggung jawab atas menanggung rugi pengguna jasa berakhir dengan memakai benda muatan yang diproduksi. ${ }^{10)}$

Berdasarkan Pasal 2 UUPK No. 8 Tahun 1999, telah ada 5 asas dalam tempat berlindung untuk pengguna jasa:

a. Dasar dari manfaat, dasar ini mengartikan bahwa mengamatkan untuk segala usaha yang ada ditempat berlindungan mewajibkan menyerahkan sesuatu hal yang berguna untuk setiap pengguna jasa dan produsen secara menyeluruh.

b. Dasar dari keadilan, dasar ini mengartikan untuk berperan serta melakukan kepada semua umat manusia supaya terwujud keadaan maksimal dan menyerahkan waktu untuk pengguna jasa dan produsen untuk memperoleh kewenangannya serta melakukan yang sudah semestinya secara sepatutnya.

c. Dasar atas keseimbangan, dasar ini mengartikan agar menyerahkan sesuatu keadaan yang sebanding diantara keperluan penggunaaa jasa, produsen dan badan usaha negara yang bersifat fisik maupun yang berhubungan dengan kejiwaan.

9) Burhanuddin S, Pemikiran Hukum Perlindungan Konsumen dan Sertifikasi halal, (Malang : UIN-MALIKI PRESS (Anggota IKAPI), 2011), hal.1.

10) Irma Nurhayati, "Pertanggung Jawaban Produsen Terhadap Konsumen Dalam Perspektif Undang-Undang Nomor 8 Tahun 1999," Jurnal Hukum Bisnis Volume 30 Nomor 1 (2011), hal.26. 
d. Dasar keamanan, dasar ini mengartikan agar menyerahkan tanggungan atas pinjaman supaya bebas dari gangguan dan terhindar dari bahaya pada pengguna jasa yang mengandung makna pemakaian, perbuatan menggunakan sesuatu muatan yang dipakai.

e. Dasar dari kepastian hukum, dasar ini mengartikan untuk produsen ataupun pengguna jasa selalu taat akan aturan dan mencapai keadilan yang mengandung makna cara menyelenggarkan tempat berlindungan penngguna jasa, dan juga negara menjamin perihal ketetapan hukum. ${ }^{11)}$

Dengan ke 5 dasar diatas tersebut terdapat maksud keinginan yang dicapai oleh pengguna jasa, tertera pada pasal 3 UUPK, yang menerangkan bahwa maksud tempat berlindung bagi penggunan jasa yaitu: ${ }^{12)}$

a. Mengangkat diri akan kesadaran, kesanggupan serta kesanggupan pengguna jasa agar melindungi diri;

b. Membawa derajat dan harga diri pengguna jasa dengan menjauhkannya pada ekes negatif penggunaan muatan;

c. Mengangkat proses memberdayakan pengguna jasa bahwa menentukan, mencari kewenangan-kewenangannya bagin pengguna jasa;

d. Menciptakan proses tempat berlindung yang tercantum unsur perihal ketetapan aturan dan terbukanya prasarana untuk mengakses segala informasi;

e. Bertumbuh akan sadarnya produsen akan betapa penting tempat berlindung pengguna jasa hingga menumbuhkan perilaku yang bertanggung jawab dan jujur akan perusahaan;

f. Mengangkat derajat muatan yang terjamin berlangsungnya atas produsen muatan benda, sehat, tentram, dan pengguna jasa terhindar dari bahaya.

Di Indonesia sendiri, kewenangan-kewenangan pengguna jasa tercantum di dalam UUPK psl 4. Salah satu nya yang harus di perhatikan oleh badan pelaku usaha PT. Jasa Marga yaitu kewenangan akan bebas dari gangguan, nyaman, terhindar dari bahaya dalam menggunakan benda muatan. Hak ini adalah hak yang sangat utama

\footnotetext{
${ }^{11)}$ Ahmad Miru dan Sutarman Yodo, Op.Cit, Hukum Perlindungan Konsumen, hal.26.

${ }^{12)}$ Indonesia. Undang-Undang Republik Indonesia Nomor 8 Tahun 1999 tentang Undang- Undang Perlindungan Konsumen
} 
dikarenakan pengguna jasa berwenang akan aman dari bahaya muatan yang menawarkan padanya. Produsen muatan tersebut dilarang digunakan karena berbahaya bahkan pengguna jasa tidak rugi keseluruhan tubuh atau roh. Kewenangan ini beroleh akan bebasnya dari bahaya utama yang diposisikan pada tingkatan penting dikarenakan selama ratusan tahun lamnya berevolusi menjadi suatu anggapan atau gagasan pemikiran akan pengguna jasa (bagi pembeli) yaitu pihak yang harus dilakukan secara waspada, bukan produsen! 1 hal yang tidak teringat dalam hubungannya dengan kewenangan agar memperoleh ketentraman yang merupakan adanya prasarana secara keseluruhan yang mencukupi prasyarat yang diatur. Di tanah air kita ini, sebagaian prasarana semuanya yaitu perpustakan, hiburan , pusat perbelanjaan, dan rumah sakit beum terpenuhi kebutuhan untuk membantu keselamatan setiap yang berkunjung. Hal inni bukan saja untuk konsumen yang mempunyai fisik normal, namun juga terlebih bagi yang lansia dan cacat fisik mengakibatkan mereka tidak berleluasa dalam jalan maupun naik tangga di tempat umum karena tingginya risiko $^{13)}$

Kewenangan berikutnya terdapat di bagian (d) yaitu kewenangan akan diindahkan segala penjelasan dan apa yang dikeluhkan suatu muatan yang dipakai. Konsumen berhak mengajukan permintaan informasi lebih lanjut. Tujuan dari hak ini adalah konsumen harus didengar pendapatnya dalam hal kondisi barang supaya kedepannya benda muatan bisa dapat menjadi lebih baik serta harus mendengarkan keluhan konsumen karena konsumen merupakan orang yang menggunakan benda.kemudian munculah pertanyaan untuk menegaskan bahwa muatan benda tersebut melanggar hak nyaman, bebas dari gangguan, dan terhindar dari bahaya si pengguna jasa.

${ }^{13)}$ Shidarta, Op.Cit, Edisi Revisi 2006, hal 22-23. 
2. Ketentuan aturan yang dibuat dan Peraturan Jalan tol

Dalam upaya penerapan perlindungan hukum terhadap konsumen penggunaan layanan fasilitas jalan tol yang telah diatur berdasarkan Psl 1 ayt (2) peraturan jalan tol yang dibuat oleh badan negara nomor 15 diTahun 2005 mengenai "Jalan Tol" yaitu perlintasan umum yang adalah bagian dari perlintasan utama yaitu perolehan metode perlintasan dan sebagai lintasan umum nasional yang mewajibkan untuk bayar jalanan ditol. Jalanan ditol juga dapat juga jalur pilihan diantara 2 jalur lintasan utama disisi lain jalanan ditol bukan juga jalur pilihan yang mana pada wilayah terkait perlintasan utama memerlukan untuk memperluas beberapa wilayah. Definisi dari jalan tol, terdapat perbedaan antara jalan tol dengan jalan umum, sehingga ada 2 kepentingan yang melekat yaitu kepentingan pihak pengelola jalan tol sebagai badan usaha/ jasa pembangunan serta pengelolaan jalan tol dan kepentingan pihak pengguna jalan tol atau yang bisa disebut dengan konsumen yaitu pengguna jalan tol. Jalan tol dapat dikategorikan sebagai cakupan aturan tempat berlindungan pengguna jasa yang pada dasarnya dipikirkan meskipun pembangunan dan penyediaan infrastruktur jalan merupakan bagian dari tugas dan wewenang pemerintah dalam rangka memberikan kesejahteraan kepada masyarakat, yang berarti masuk dalam kategori hukum publik. Namun dalam pembangunan jalan tol pemerintah tidak bisa memenuhi kebutuhan atas penyediaan infrastruktur jalan secara menyeluruh diakibatkan oleh kurangnya dana yang dimiliki pemerintah maka pemerintah menyerahkan pembangunan dan penyediaan infrastruktur jalan tol kepada pihak swasta. ${ }^{14)}$ Dengan pengalihan pembangunan dan penyediaan infrastruktur jalan tol dari pemerintah kepada swasta yang kemudian menjadi pengelola dan menunjukkan bahwa jalan tol menjadi bisnis jasa pembangunan jalan yang dikelola oleh perusahaan swasta.

14) Badan Pengatur Jalan Tol Kementerian Pekerjaan Umum, 2010, Peluang Investasi Jalan Tol di Indonesia, Hal. 24. 
Perusahaan yang menjadi pengelola jalan tol diperkenankan untuk menarik tarif tol sesuai dengan peraturan pemerintah sehingga pengguna jalan tol sebagai konsumen memiliki hak-hak yang harus dipenuhi oleh pengelola jalan tol. ${ }^{15)}$.

Kewenangan-kewenangan pengguna jalanan ditol yang menggunakan prasarana layanan jalan ditol yang ketentuannya diatur pada psl.87 serta psl.88 Peraturan badan negara nomor 15 ditahun 2005 mengenai "Jalan Tol" ini berwenang meminta segala hal yang mengenai kerugian langsung kepada BUJT Jalan Tol dan berwenang untuk dapat prasarana layanan SPM yang dimaksudkan Psl.8 Peraturan badan negara nomor 15 ditahun 2005 mengenai "Jalan Tol" akan tetapi adanya Psl.4 UUPK No.8 diTahun 1999 mengatur secara tegas mengenai kewenangan-kewenangan yang dimiliki bagi pengguna jasa, bagaimana pun para konsumen pengguna jasa layanan jalan ditol yang bukan dan yang tidak adalah pengguna jasa dari prasarana jalanan ditol. Mengenai ini terwujudnya tempat berlindungan aturan atas kewenangan-kewenangan konsumen jalanan ditol, BPJT merupakan alat pengatur kecepatan jalanan ditol yang menyaratkan produsen badan usaha jalan tol agar menyerahkan segala sesuatu terhadap layanan yang utama sebagai kontrasepsi proses membayar jalanan ditol kpada pengguna jasa layanan jalan bebas hambatan di jalan layang yang bersangkut pautkan atas pelaksanaan rencana yang telah dikembangkan terhadap jalanan bebas hambatan. Begitu pun hasil wawancara bersama Bapak Refly Harun dapat ditarik kesimpulan mengenai segala putusan yang telah ditetapkan oleh pengurus atau dewan pimpinan oleh perusahaan PT. Jasa Marga tercantum dalam No.181/KPTS Tahun 2011 mengenai tempat berlindung yang telah diberikan pelaku usaha kepada konsumen jalanan ditol, hal ini dilihat dari ketentuan usahanya dari sisi pelaku usaha badan usaha perusahaan ini menyatakan layanan prasarana jalanan ditol yang bermanfaat tanpa adanya halangan yang mewujudkan

\footnotetext{
${ }^{15)}$ Ibid, Hal. 14.
} 
bebas dari gangguan, nyaman dan lancar menyediakan fasilitas yang sangat utama sebagai kontrasepsi proses membayar jalanan ditol kepada pengguna jasa sesuai dengan SPM dalam ketentuannya di psl.8 Peraturan badan usaha negara No.15 diTahun 2005 mengenai "Jalan Tol" melindungi kewenangan-kewenangan pengguna jasa layanan jalanan ditol dalam ketentuan psl.87 dan 88 Peraturan badan usaha negara No.15 diTahun 2005 mengenai “Jalan Tol” lalu psl.4 UUPK No.8 diTahun 1999 namun fakta yang sebenarnya tidak begitu maksimal, masih saja didapati berbagai macam persoalan suatu peristiwa keadaan dari pihak pengelola badan usaha jalanan ditol wajib melihat persyaratan fasilitas apalagi pada saat kejadian pelemparan batu yang terjadi. Dimana seharusnya pihak dari pelaku usaha Jasa Marga ini mengantisipasi atas hal nya kejadian tersebut. Kejadian peristiwa ini bukan hanya terjadi sekali saja, sering banyaknya kasus pelemparan batu yang terjadi di wilayah jalan tol yang dapat mengakibatkan hilangnya hajat hidup orang banyak.

3. Sanksi Pidana menurut Kitab Undang-Undang Hukum Pidana (KUHP) dan ketentuan UU lainnya.

Ketentuan aturan hukum yang dibuat oleh manusia yang menetapkan suatu tindakan dalam medan perkara kejahatan secara utama ditemukan dalam buku aturan perkara kejahatan yang telah dibuat oleh pemerintah. Di tanah air kita ini penerapan buku di atas hal persatuan pada tahun 1918, yaitu awal pertama diberlakukan Wetboek-van-Strafrecht vor Nederlandsch-Indie. Aturan atas kriminal ini sendiri terdiri atas kelompok aturan umum. Diseluruh aspek aturan umum tersebut, yang paling banyak bersangkutan dengan tempat berlindungnya para pengguna jasa yaitu konsumen atasb kejahatan kriminal dan aturan tentang usaha dan kegiatan negara. ${ }^{16)}$ Seseorang yang telah melawan

${ }^{16)}$ Shidarta, Op.Cit, Edisi Revisi 2006, hal 112-113. 
hukum, tentu akan mendapatkan konsekuensi atas hukuman yang dia perbuat. Perlawanan hukum terdiri dari 2 : yang pertama adalah Pelanggaran yaitu sesuatu yang diperbuat atas pelanggaran aturan yang dilakukan secara sengaja maupun tidak; yang tidak menderita luka-luka atau meninggalnya orang. Yang kedua yaitu tentang kejahatan, beda halnya dengan yang pertama, melainkan sesuatu yang dilakukan secara sengaja ataupun tidak menyebabkan sesseorang luka-luka bahkan meninggalnya orang tersebut.. ${ }^{17)}$ ajaran yang dimaksud terhadap perlawanan hukum yang diatas, ialah sebagai berikut:

a. Perlawanan hukum kejahatan merupakan sesuatu yang diperbuat sebagaimana dilihat atas kejahatan kriminal yang bertentangan dengan keadilan, walaupun penggunaan itu belum diatur dalam aturan hukum. mala per se atau biasanya yang diisebut dengan Perlawanan hukum artiinya sesuatu yang diperbuat ini telah dianggap kejahatan walaupun belum adanya aturan hukum yang mana sesuatu yang diperbuat merugikan orang lain serta tidak pantas untuk dilakukan.

b. Perlawanan hukum pelanggaran merupakan sesuau yang diperbuat akan mengetahui perlawanan hukum sebagaimana yang telah ada dalam aturan hukum. Nama lain dari perlawanan hukum ini yaitu mala quia prohibia yaitu sesuatu yang diperbuat dilihat sebagai perlawanan hukum yang sudah ada dalam aturan hukum. ${ }^{18)}$

Adanya aturan yang dibuat oleh pemerintah atas aturan hukum kejahatan kriminal tidak ada ditemukannya kalimat "pengguna jasa" yang secara implisit dapat ditarik beberapa pasal yang memberikan tempat berlindungnya hukum bagi pengguna jasa :

a. Pasal 359: Barang siapa oleh karena kehadirannya yang dapat menimbulkan meninggalnya seseorang, dihukum ancaman aturan hukum kejahatan kriminal dipenjara selama 5 tahun atau setahun.

b. Pasal 360: Barang siapa yang oleh karena kehadirannya menimbulkan seseorang menderita akan terluka parah, dihukum ancaman kurungan dipenjara paling lama 5 tahun atau setahun. Sehingga menimbulkan orang lain menderita terluka parah yang diakibatkan adanya sakit, cacat permanen atau hilangnya pekerjaan

17) Soedjono Dirdjosisworo, Pengantar Ilmu Hukum, Edisi 1 cetakan 13, (PT. Radjagrafindo; Jakarta, 2010) Hal.74-75.

${ }^{18)}$ Roni Wiyanto, Asas-Asas Hukum Pidana, Cetakan ke-1, (Mandar Maju: Bandung, 2012), Hal. 169. 
selama waktu tertentu, dihukum ancaman dipenjara 9 bulan atau bayar dengan RP300,00. ${ }^{19)}$

Ketentuan lain yang berkaitan dengan pidana konsumen tentang kecelakaan jalan tol ini bisa kita lihat pasal-pasal yang berkaitan. Misalnya, yang terdapat pada aturan yang dibuat oleh pemerintah mengenai Jalan No 38 diTahun 2004 Psl 1 ayt (19), Pasal 63, 64 dan pasal 65 .

\section{B. Tanggung Jawab Pelaku Usaha}

Berkewajiban dalam menanggung sesuatu yaitu definisi dari tanggung jawab. ${ }^{20)}$ badan pelaku usaha yang menanggung dalam usaha pencapaian sejahtera masyarakat. ${ }^{21)}$ badan pelaku usaha mewajibkan untuk ngasih kerugian kepada konsumen yang mana telah diatur dalam UUPK No. 8 Tahun 1999 Psl 7 bagian g. Selain terdapat pada UUPK ganti kerugian juga terdapat dalam Pasal 87 Peraturan Pemerintah Nomor 15 tahun 2005 yaitu pengguna jasa jalanan ditol mempunyai wewenang untuk meminta kembali atas kerugian yang dilakukan oleh pelaku badan usaha serta pasal 92 Peraturan Pemerintah Nomor 15 diTahun 2005 mengenai "Jalan tol" adalah badan pelaku usaha wajib memberi ganti kerugian yang dialami oleh konsumen jalanan ditol oleh kesalahan dari badan pelaku usaha.

Asas dasar tentang kewajiban menanggung ssesuatu yaitu keadaan sangat penting yang ada di dalam aturan perlindungan pengguna jasa, dalam kejadian perisiwa tersebut perbuatan melanggar kewenangan pengguna jasa memerlukan kewaspadaan dalam menganalisis atas suatu kewajiban untuk menanggung

19) Shidarta, Op.Cit, Edisi Revisi 2006, hal 112-113.

${ }^{20)}$ https://kbbi.web.id/tanggung\%20jawab, diakses tanggal 17 September 2018

21) Janus Sidabalok, Hukum Perlindungan Konsumen di Indonesia, (Bandung : Citra Adhitya Bakti, 2014), hal.71. 
dibedakan pada pihak yang ada hubungannya. ${ }^{22)}$ Pada umumnya, asas-asas berkewajiban menanggung sesuatu ini dibedakan menjadi: ${ }^{23)}$

a. Asas tentang kewajiban menanggung atas kesalahan (fault liability atau liability based on fault) : hal yang mendasar yang berlaku pada aturan kejahatan kriminal dan perdata. Pada aturan hukum yang telah dibuat pada perdata yang khususnya terdapat pada Psl 1365 - 1367, aturan dasar ini mengatakan jika orang baru diminta untuk berkewajiban menanggung secara hukum jika bagian terkecil akan kesalahannya yang mana bertentangan dengan aturan hukum. Pengertian "hukum", bukan hanya yang berlawanan dengan aturan yang dibuat, melainkan kelayakan dan norma yang baik dalam lingkungan masyarakat. ${ }^{24)}$

b. Asas tentang prasangka untuk selalu berkewajiban dalam menanggung (presumption of liability principle). Asas inimengatakan bahwa pelaku selalu dianggap untuk mewajibkan menanggung kesalahannya sampai bisa dibuktikan kalau dia tak bersalah. ${ }^{25)}$

c. Asas tentang prasangka untuk tidak wajib dalam menanggung : asas ini kebalikannya dari asas yang ke dua. Asas prasangka ini cukup dikenal di seputaran pembayaran pengguna jasa yang sangat terbatas, namun biasanya secara commonsense dibetulkan. ${ }^{26)}$

d. Asas tentang kewajiban menanggung seutuhnya (strict liability) selalu diidentikkan asas kewajiban menanggung absolut (absolute liability). ${ }^{27}$ ada tanggapan mengenai asas ini yaitu prinsip kewajiban menanggung yang ditetapkan kesalahan bukan sebagai titik utama ditentukan. Namun, ada pengecualian-pengecualian yang memungkinkan agar dibebaskan dari kewajiban menanggung, salah satunya keadaan force majeure. Sebaliknya, absolute liability adalah asas kewajiban untuk menanggung tanpa permasalahan dan tanpa adanya kecualian. Dalam strict liability, hub itu harus ada, sementara pada absolute liability, dapat saja si pelaku yang dimintai kewajibannya dalam menanggung atas kesalahannya. ${ }^{28)}$

Penyelesaian atas tuntutan pengakuan dari konsumen jalanan ditol diganti oleh badan pelaku usaha Jasa Marga apabila rugi yang dialami yaitu secara langsung yang terjadi karena kesalahan oleh pihak perusahaan dalam layanan prasarana dijalan tol. Penyelesaian atas tuntutan pengakuan dari konsumen jalanan ditol didahulukan dengan cara perundingan agar beroleh kata persetujuan, dalam hal

${ }^{22)}$ Celina Tri Siwi Kristianti, Hukum Perlindungan Konsumen, Cetakan Kedua, (Jakarta: Grafika, 2009),Hal.92.

${ }^{23)}$ Shidarta, Op.Cit, Edisi Revisi 2006, hal 72.

24) Ibid, hal.73.

25) Ibid, hal.75.

26) Ibid, hal.77.

27) Ibid.

28) Ibid, hal.78. 
tersebut banyaknya konsumen jalanan ditol terlibat akan rugi yang dideritanya diakibatkan layanan prasarana belum terpenuhi dan wewenang akan keselamatan pengguna jalanan ditol. Hal ini menjadi suatu kewajiban dalam menanggung dari pihak badan usaha Jasa Marga agar mengganti rugi yang dialami oleh para konsumen, peristiwa ini sudah berlaku akibat kelalaian dari Pihak PT Jasa Marga yang tidak sepenuhnya memperhatikan kondisi jalan tol khususnya kawat yang adadi JPO sudah rusak hingga terjadinya pelemparan batu sesuai dengan aturan yang dibuat dalam Psl 19 ayt (1\&2), UUPK No.8 diTahun 1999 serta Psl 92 PP No.15 diTahun 2005 menegaskan Badan pelaku Usaha diwajibkan mengganti rugi yang dialami oleh konsumen jalanan ditol.

\section{PENUTUP}

\section{A. Kesimpulan}

Berdasarkan penelitian dan pembahasan yang telah penulis uraikan diatas tersebut, maka dapat ditarik suatu kesimpulan sebagai berikut:

1. Tempat berlindungan yang telah diberikan oleh pelaku badan usaha PT. Jasa Marga (Persero) Tbk ini adalah dengan adanya ketentuan SPM jalanan ditol yang telah diperlakukan terdapat di dalam PP No.15 diTahun 2005 mengenai “Jalan Tol” di psl 87 dan psl 88 mengatur tentang kewenangan-kewenangan konsumen pengguna jalanan ditol serta di dalam UUPK Psl.4. para pihak dari pelaku badan usaha dari perusahaan Jasa Marga ini mewajibkan untuk melindungi bagi para konsumen jalanan ditol hal-hal mengenai sarana dan prasarana aman dan keselamatan telah diberikan. Namun nyatanya hal yang berlangsung terjadinya masih banyak kondisi jalanan ditol yang tidak mencukupi sehingga menimbulkan peristiwa korban dan menyebabkan rugi yang besar akibat kurangnya penggarapan dan penjagaan sikon jalanan ditol seperti kondisi pagar jaring-jaring di JPO yang berbolong alias sudah rusak dan 
tidak adanya CCTV yang ditempatkan di titik rawan terjadinya pelemparan batu oleh orang gila atau iseng di JPO namun nyatanya CCTV hanya menyorot di bagian jalan tol saja, hal ini yang menjadi kurangnya barang bukti jika suatu saat terjadi hal serupa.

2. Menanggung segala sesuatu yang diberikan badan pelaku usaha PT. Jasa Marga, sangat wajib mengusahakan agar lingkungan yang ada dijalan tol selalu dalam nyaman, aman dan selamat. Disampping itu juga badan pelaku usaha Jasa Marga ini pun wajib memperhatikan banyaknnya keluhan atas tuntutan pengakuan oleh konsumen jalanan ditol yang telah rugi secara langsung. Tanggung jawab dari badan usaha ini adalah menanggung segala sesuatunya dari keadaan lalai nya pada sikon jalanan ditol terutama pada JPO

\section{B. Saran}

Saran dari penulis adalah:

1. Untuk pihak-pihak yang terkait seharusnya dapat segera mengantisipasi dari awal atas kejadian serupa, dimana yang seharusnya badan pelaku usaha Jasa Marga ini memasang CCTV (Closed Circuit Television) di setiap JPO dan Fly Over yang melintas di atas jalan tol supaya dapat terpantau dan mengantisipasi hal-hal kajadian lain. Selanjutnya, dibuatnya aturan-aturan yang melarang setiap masyrakat untuk berhenti di area pinggiran JPO atau Fly over, Dikarenakan dua tempat tersebut kerap dipakai untuk berkumpulnya orang-orang sehingga berpotensi menjadi lokasi pelemparan atau terjadinya tawuran antar geng. Khususnya kawat-kawat yang ada di JPO pun harus rutin diperiksa secara berkala agar dipastikan terpasang kuat. 
2. Hendaknya pemerintah dan aparat penegak hukum melakukan pengamanan, menindak tegas bagi para pelaku dan menetapkan sanksi yang jelas kepada setiap meakukannya kegiatan baik itu snegaja maupun akibat lalai, hal ini perlu juga menerapkan ketentuan aturan yang dibuat misal: UU yang berlaku dan juga bagi orang serta produsen supaya mengakibatkan para pelakunya kapok untuk melakukannya lagi seperti dalam kejadian pelemparan batu oleh orang iseng yang sering terjadi di JPO.

\section{DAFTAR PUSTAKA}

\section{A. Buku}

Badan Pengatur Jalan Tol Kementerian Pekerjaan Umum, Peluang Investasi Jalan Tol di Indonesia,(2010).

Burhanuddin S, Pemikiran Hukum Perlindungan Konsumen dan Sertifikasi halal, (Malang : UIN-MALIKI PRESS (Anggota IKAPI), 2011).

Dewi, Eli Wuria. Hukum Perlindungan Konsumen, (Yogyakarta: Graha Ilmu, 2015).

Dirdjosisworo, Soedjono. Pengantar Ilmu Hukum, Edisi 1 cetakan 13,

(Jakarta: PT. Radjagrafindo, 2010).

Kansil, C.S.T, Engelien Palandeng dan Altje Agustin Musa. Tindak Pidana Dalam Undang-Undang Nasional, (Jakarta: Jala Permata Aksara, 2009).

Kristianti, Celina Tri Siwi, Hukum Perlindungan Konsumen, Cetakan Kedua, (Jakarta: Grafika, 2009)

Miru, Ahmad dan Sutarman Yodo, Hukum Perlindungan Konsumen. 
Nurhayati, Irma, "Pertanggung Jawaban Produsen Terhadap Konsumen Dalam Perspektif Undang-Undang Nomor 8 Tahun 1999,” Jurnal Hukum Bisnis Volume 30 Nomor 1 (2011).

Shidarta, Hukum Perlindungan Konsumen Indonesia, Edisi Revisi 2006, (Grasindo: Jakarta, 2006).

Sidabalok, Janus, Hukum Perlindungan Konsumen di Indonesia, (Bandung : Citra Adhitya Bakti, 2014).

Wiyanto, Roni, Asas-Asas Hukum Pidana, Cetakan ke-1, ( Bandung; Mandar Maju, 2012)

\section{B. Undang-Undang}

Indonesia. Undang-Undang Republik Indonesia Nomor 8 Tahun 1999 tentang UndangUndang Perlindungan Konsumen.

Indonesia. Undang-Undang Republik Indonesia Nomor 30 Tahun 2004 tentang Jalan.

Indonesia. Peraturan Pemerintah Nomor 15 tahun 2005 tentang Jalan Tol.

\section{Kamus}

Kamus Besar Bahasa Indonesia https://kbbi.web.id/tanggung\%20jawab

\section{Wawancara}

Harun, Refly. Wawancara dengan penulis, selaku Komisaris PT. Jasa Marga (Persero) periode 2015-2018, Ahli Hukum Tata Negara yang juga selaku dosen Fakultas Hukum di Universitas Tarumanagara. Daerah Kebon Jeruk, Jakarta Barat, 09 Desember 2018. 


\section{E. Website}

News, Detik. "Pelemparan Batu ke Mobil di Tol dari JPO Pondok Gede Terjadi

2 Kali" https://m.detik.com/news/berita/4060679/pelemparan-batu-

ke-mobil-di-tol-dari-jpo-pondok-gede-terjadi-2-kali , Diakses pada tanggal 10/08/2018.

Marga, Jasa. "Sekilas Jasa Marga" http://jasamarga.com/public/id/infoperusahaan/ProfilPerusahaan/Ov erview.aspx, Diakses pada tanggal 10/08/2018 